\title{
Plechów. Historia majątku ziemskiego, pod red. Waldemara Bukowskiego, ss. 464, Kraków 2016, Wydawnictwo Societas Vistulana
}

Recenzowana monografia stanowi efekt studiów nad dziejami podkrakowskiej wsi Plechów (obecnie w gminie Kazimierza Wielka, w województwie świętokrzyskim) od jej prehistorycznych początków po czasy współczesne, koordynowanych przez Waldemara Bukowskiego, kierownika bardzo zasłużonej w dziedzinie badań regionalnych Pracowni Słownika Historyczno-Geograficznego Małopolski w Średniowieczu Instytutu Historii Polskiej Akademii Nauk.

Otwiera ją poświęcony archeologii artykuł „Z prahistorii dorzecza Jawornika”, pióra Krzysztofa Tuni z Instytutu Archeologii i Etnologii Polskiej Akademii Nauk, w którym Autor przedstawił także przeszłość geologiczną badanej okolicy i jej krajobraz naturalny.

Następnie Jacek Laberschek ze wspomnianej Pracowni w rozdziale pod niezbyt zgrabnym tytułem: „Plechów w średniowieczu i w XVI wieku (do 1576 roku)”, poddał analizie dzieje średniowiecznego i wczesnonowożytnego (do 1576) Plechowa, opierając się przy tym na drukowanym materiale dyplomatycznym oraz źródłach rękopiśmiennych przechowywanych w Archiwum Narodowym w Krakowie. Tu na uwagę zasługuje zwłaszcza wyjaśnienie szeregu nieznanych dotąd zagadnień genealogicznych tyczących się właścicieli wspomnianego majątku.

Jego rozważania kontynuował Mateusz Wyżga z Instytutu Historii i Archiwistyki Uniwersytetu Pedagogicznego w Krakowie w artykule „Plechów i jego mieszkańcy w latach 1576-1795", koncentrując się nie tylko na genealogii zmieniających się właścicieli majątku, ale również na ludności chłopskiej, zabudowie wsi i zespołu dworskiego oraz zajęciach mieszkańców wsi.

Z kolei Konrad Meus z tego samego Instytutu poświęcił swój rozdział zatytułowany identycznie jak poprzedni, tylko z innymi datami (1795-1918), czasom niewoli narodowej. Na przykładzie Plechowa pokazał losy ziem polskich przechodzących z rąk jednego zaborcy do drugiego. Przeprowadził nadto interesujące studia demograficzno-historyczne i uzyskał interesujący obraz ludności wiejskiej tego czasu, wydobywając z zapomnienia anonimowych dotąd mieszkańców Plechowa.

Kolejny autor, Marcin Chorązki z Instytutu Pamięci Narodowej (Oddział w Krakowie), w tekście pod tym samym tytułem co oba poprzednie, tyle że z późniejszymi datami (19181945), przedstawił losy tytułowego majątku w okresie międzywojennym i w czasie II wojny światowej, aż do usunięcia właścicieli przez władze komunistyczne. Jego rozważania uzupełniają fragmenty wspomnień świadka historii Tadeusza Zwierkowskiego, fascynujące i dające wgląd w życie codzienne ziemian. 
Ostatni rozdział autorstwa Grzegorza Tracza z Katedry Prawa Cywilnego Wydziału Prawa i Administracji Uniwersytetu Jagiellońskiego zatytułowany „Sytuacja prawna byłych właścicieli nieruchomości ziemskich w III Rzeczypospolitej” stanowi wartościowe uzupełnienie książki i zawiera klarowne wyjaśnienie zawiłych kwestii związanych z sytuacją prawną dóbr ziemskich w XX w., zwłaszcza w kontekście uwłaszczeń, nacjonalizacji i ewentualnych procesów odzyskiwania nieruchomości przez osoby prywatne. Przez to może nawet być użyteczny dla byłych właścicieli majątków ziemskich i ich potomków. Autor wykorzystał tu swoje doświadczenia zawodowe i życiowe. Zamieszczone zdjęcia, wykresy, tabele i mapy, nie tylko zwiększają atrakcyjność książki, ale stanowią cenne uzupełnienie prezentowanych treści.

Warto podkreślić, że omawiana praca stanowi efekt niecodziennej współpracy redaktora i autorów z Alicją i Grzegorzem Traczami, którzy przed laty zainteresowali się reliktami majątku ziemskiego Plechów - pozostałości te obejmowały zniszczony murowany budynek, będący częścią starszego, nieistniejącego już dziś drewnianego dworu, i zaniedbany park. W 2008 r. podjęli oni działania mające na celu przywrócenie dawnego blasku założeniu dworskiemu, co przy aprobacie i wsparciu udzielonemu im przez spadkobierczynię majątku, Krystynę Sobierajską, zrealizowali do 2015 r. Prace budowlane, po wcześniejszym uporządkowaniu parku i opracowaniu przez Marka Cemplę planu architektonicznego dla budynku, rozpoczęli w 2012 r. przy współpracy Karoliny Błażuckiej i Marka Błażuckiego. Doszli jednak do przekonania, że: ,byłaby to praca niepełna i przez to niezrozumiała, bez próby odtworzenia jego [majątku plechowskiego - S.S.] dziejów. Bez wydobycia z przeszłości nazwisk i losu ludzi, którzy w miejscu tym żyli, przebywali i je tworzyli, oddziałując tym samym na dalsze otoczenie i Kraj, w którym wiedli żywot"1. Majątek plechowski należy do tej niewielkiej grupy zabytków, które doczekały się pełnej rewitalizacji, idącej w parze z opracowaniem ich historii, co przecież stanowi o istocie i duchu miejsca.

Chronologiczne ujęcie historii Plechowa wyróżnia także forma narracji, co przy dużej liczbie przytaczanych źródeł, faktów, miejsc, nazwisk, zjawisk i analiz ułatwia lekturę. Czytelnik pozostaje z wrażeniem uporządkowania prezentowanych treści. Szkoda tylko, że brak bibliografii, której nie zastąpi załączony wykaz skrótów. Autorzy poszczególnych rozdziałów odwołują się przecież do wielu źródeł i opracowań, więc jeśli czytelnik chciałby poznać pełne zestawienie literatury i źródeł, będzie musiał przeglądać przypisy karta po karcie. Można też było zamieścić słowniczek terminów staropolskich, co ułatwiłoby lekturę fascynatom historii lokalnej, osobom niekoniecznie zajmującym się historią zawodowo.

Połączenie rzetelnego opracowania zagadnienia z lekkim piórem autorów powoduje, że treść, pomimo bogactwa szczegółów, nie jest trudna w odbiorze. Historia Plechowa przedstawiona jest na tle burzliwych dziejów Rzeczypospolitej, której losy w pewnej mierze znajdowały odzwierciedlenie w nadnidziańskich realiach. Jest to lektura obowiązkowa również dla osób zainteresowanych losami ziemiaństwa i ich majątków. W szerszym kontekście, informacje zawarte w monografii mogą być użyteczne również dla historyków gospodarki i demografów. Poprzez swoją konstrukcję, dobrze opracowane zagadnienie uwzględniające

${ }^{1}$ Plechów. Historia majatku ziemskiego, red. Waldemar Bukowski, Kraków 2016, s. 9. 
kontekst bliższej i dalszej okolicy, a także tło gospodarcze i polityczne w skali ogólnokrajowej, recenzowana monografia może stanowić interesujący punkt odniesienia, by nie rzec wzór, dla kolejnych tego typu opracowań.

Sebastian Stańczyk

Uniwersytet Pedagogiczny w Krakowie 